\title{
Does the New Kindergarten Teacher Education Program in Norway Provide Good Conditions for Professional Kindergarten Teachers?
}

\author{
Wenche Aasen ${ }^{1}$, Alicja R. Sadownik ${ }^{2, *}$ \\ ${ }^{1}$ Western Norway University of Applied Sciences, Norway \\ ${ }^{2}$ Kindergarten Knowledge Centre for Systemic Research on Diversity and Sustainable Futures, \\ Western Norway University of Applied Sciences, Norway
}

Copyright $\bigcirc 2019$ by authors, all rights reserved. Authors agree that this article remains permanently open access under the terms of the Creative Commons Attribution License 4.0 International License

\begin{abstract}
This partly descriptive, partly critically reflective, argumentative article analyses the Norwegian kindergarten teacher education program through the three concepts that are mentioned in its national guidelines: research-based, profession-oriented, and practice-related education. An inseparable correlation between these at the level of higher educational institutions is a condition for the development of professionalism and competences to act that are, again, a condition for exercising professional knowledge in practice in kindergartens. A question that is posed continually in this chapter is how the various aspects of profession-oriented, research-based, and practice-related kindergarten teacher education can become conditions for educating professional kindergarten teachers. The conclusions address both the institutional and national levels at which certain improvements can be implemented to strengthen the professional growth of kindergarten teachers and, thereby, kindergarten quality.
\end{abstract}

Keywords Kindergarten Teacher Education, Norway, Research-based, Profession-oriented, Practice -related

\section{Introduction}

There is a strong political expectation in Norway that kindergartens are associated with professionalism and educational quality that ensures that children are provided with optimal opportunities for all-round development in kindergartens. It implies an expectation that kindergarten teachers are qualified enough to fulfill children's needs for care, play, learning, and cultural formation in a democratic society [1]. The kindergarten teacher education course of study provides a bachelor's degree that creates certain expectations as to the professional development of kindergarten teachers. Kindergarten teacher education in Norway received a new national framework under the reform in 2012 [2]. The reform aimed at strengthening kindergarten teachers as professionals, which would contribute to the general improvement of kindergarten quality. At the time, kindergarten quality was reported to be variable, and it differed highly from kindergarten to kindergarten depending on the competences of personnel [3]. Since kindergarten teachers in Norway not only work with the other professional kindergarten teachers, but also with unqualified assistants, their professional competences together with outreach and leadership skills are significantly important for the quality of pedagogical work in kindergartens. This is why kindergarten teacher education is not only seen as teacher education but also as leader education [2].

In order to develop good teachers and good leaders the kindergarten teacher education must be research-based, practice-related, and profession-oriented [2]. The connection between these three concepts support the foundation for kindergarten teachers as professionals. In this paper these three aspects of kindergarten teacher education will be discussed as good conditions for educating good kindergarten teachers. In order to do this, the culturally anchored understandings of good kindergarten and good kindergarten teachers requires explanation.

\section{Good Nordic Childhoods and Kindergartens}

The understandings of good (child) care are always connected to other values in certain cultures. Norway, along with other Nordic cultures, has developed the values of child-centeredness and welfare as central to society and 
its institutions [4]. The value of welfare stands for democracy, egalitarianism, freedom, emancipation, cooperation, and solidarity, while child-centeredness relates them to the youngest citizens-children. More precisely, "democracy ensures that children have a voice; egalitarianism ensures that children's voices have influence; freedom expands their horizons and the sphere of their influence; and emancipation gives them room to explore their options" [5]. "These principles are balanced by cooperation and solidarity, which require compromise and mutual responsibility, and thereby focus on the relationship between the individual and the group" [6].

These values have always been articulated in the Framework Plans for Kindergartens [1, 7, 8, 9] that anchors kindergarten institutional practices in cultural values, which, in Norway, are universal humanist values including respect for human dignity and nature, charity, forgiveness, equality, and solidarity [7:7].

This means that within the institution of the kindergarten the child is recognized as a subject and actor in his/her life $[10,11,12]$ who is actively participating in kindergarten life [13]. Seeing a child as a subject certainly places his/her most natural activity in an important position. Play in the Nordic holistic approach is seen as an all-round learning activity [14] as children's way of being [15] as the most important arena for children's agency and participation [13, 16] and as children's labor in terms of the most meaningful, essential human activity $[17,18]$ This establishes free play as the dominant part of daily kindergarten activities [19].

\section{Ever Better Kindergarten Teacher Education}

The cultural values connected to the understanding of the good childhood and, thereby, good kindergartens are present in defining the profession of kindergarten teacher. This means that professional kindergarten teachers are obliged to reflect and realize the values articulated in the curriculum document [1]. This is because a profession in the Norwegian context is understand as a job that develops in response to a social need (in this instance, for childcare) and, thereby, has a social mandate for realizing the required tasks. Currently, the kindergarten social mandate is as follows:

The Kindergarten shall, in collaboration and close understanding with the home, safeguard the children's need for care and play, and promote learning and formation as a basis for an all-round development. The Kindergarten shall be based on fundamental values in the Christian and humanist heritage and tradition, such as respect for human dignity and nature, on intellectual freedom, charity, forgiveness, equality and solidarity, values that also appear in different religions and beliefs and are rooted in human rights.

The children shall be able to develop their creative zest, sense of wonder and need to investigate. They shall learn to take care of themselves, each other and nature. The children shall develop basic knowledge and skills. They shall have the right to participate in accordance with their age and abilities.

The Kindergartens shall meet the children with trust and respect, and acknowledge the intrinsic value of childhood. They shall contribute to well-being and joy in play and learning, and shall be a challenging and safe place for community life and friendship. The Kindergarten shall promote democracy and equality and counteract all forms of discrimination [20].

Since its implementation includes distinctive specialist knowledge, developing an educational program that will impart students with the necessary qualifications for the profession is necessary [21].

According to the national guidelines for Kindergarten Teacher Education the professional kindergarten teacher:

- reflects critically on his/her own practice;

- reflects on pedagogical/educational work in light of current steering documents and ethical requirements;

- has insight into and an understanding of ethnical requirements and dilemmas, especially those connected to respect, responsibility, and power relations;

- analyzes and is able to reflect critically on professional and ethical challenges connected to educational work with children (their development, play, learning, and formation);

- is able to justify, communicate, and practice the kindergarten social mandate and its value base;

- $\quad$ is able to manage and lead staff;

- is able to reflect critically on his/her own values, attitudes, and ways of being and is able to act in line with kindergarten values and goals $[2,21]$.

In order to facilitate this direction of kindergarten teacher professional development, kindergarten teacher education was reformed. During the recently conducted reform, the program was transformed into a three-year bachelor's degree with 180 ECTS credits. In contrast to the former model, the reformed model departs from scientific disciplines and instead focuses on interdisciplinary areas of knowledge that are meant to mirror the interdisciplinary character and complexity of kindergarten daily life. The interdisciplinary areas of knowledge in current kindergarten teacher education are as follows:

- child development, play, and learning;

- $\quad$ art, culture, and creativity;

- $\quad$ social sciences, religion, and ethics;

- $\quad$ language, text, and mathematics;

- $\quad$ nature, health, and motion;

- leadership, cooperation, and developmental work.

Additionally during the third year of studies, the students can choose a specialization (20 ECTS credits) and work on their research-based bachelor theses. The subject of pedagogy plays a unique role in kindergarten teacher education. It delves into all areas of knowledge and is 
responsible for the general coherence among them and for students' professional and personal growth. The responsibility of pedagogy in the research-based, profession-oriented and practice-related dimension of the educational program is of equal importance (Norwegian Ministry of Science and Education 2012).

The way the subject of pedagogy does this depends on the year of the course. During the first year when Child development, play, and learning and Art, culture, and creativity are the primary areas of study, the subject of pedagogy refers the content to issues of the child as a subject $[10,22]$ the child's all-round development, dynamics of children's groups $[15,23]$, and the playful teacher $[15,24]$. Like the Norwegian kindergarten, kindergarten teacher education follows the holistic Nordic model, and its understanding of good childhood with a special focus on the inseparable relation between play and learning is "served" to the students[14, 15]. This is followed up by practical training during which students participate in daily kindergarten routines, observe children's play and themselves as teachers capable of playing in play situations. In addition to this, they realize tasks in the art-related area of knowledge.

During the second year of the course, the subject of pedagogy builds a bridge between following areas of knowledge: 1) Social sciences, religion, and ethics, 2) Language, text, and mathematics, and 3) Nature, health, and motion. This is done by focusing on the educational leadership of children's groups and their learning processes, kindergarten units [25], and parental cooperation (Glaser 2018). Didactic planning [27] is also of equal importance. These areas of knowledge can be implemented and realized in the institutionalized life of kindergartens through reflective and tactful leadership, which is why this is chosen as the glue that permits joining areas of knowledge dominated by radically different disciplines like mathematics, language and literature, and physical education. All of this is followed up by practical training in in-service kindergartens where students take over the leadership of children groups and staff teams. Of equal importance is the interdisciplinary project completed during the second year of the course known as The Difficult Conservation [see also: 28, 29], in which students use drama and their theoretical knowledge to deal with and discuss real-life "kindergarten problems" connected to parental cooperation in a multicultural society.

During the third year of the course, the subject of pedagogy integrates the areas of knowledge served that vary depending on the specialization. Nevertheless, the integrating subject of pedagogy focuses on the educational leadership of kindergarten units, where: the kindergarten is understood as a learning organization [25] in which the leadership of quality improvement processes $[30,31]$ and cooperation with other institutions are central. Classes on campus are followed up with practical training in which students, supervised by kindergarten teachers, conduct developmental work/projects aimed at improving some aspect of kindergarten quality. Since the developmental projects include all the staff of the kindergarten unit, the students develop team-leadership skills and the ability to put ideas and theories into action. As mentioned above, these abilities are seen by the Norwegian state as those that have the greatest impact on kindergarten quality in terms of making it less random [32, 33].

The impact of kindergarten teacher education on kindergartens is also safeguarded by making kindergarten teacher education practice-related. The first dimension of this is connected to equalizing academic teachers and in-service teachers from kindergartens by applying the term of "teacher educator." Teachers representing the "theoretical" and "practical" fields are recognized as "teacher educators" by the reform document [2].

Moreover, the national guidelines for kindergarten teacher education indicates the necessity of coherence between theoretical reflections and students actions in practice. During the 100 days of obligatory practical training, students try to implement theoretical knowledge in practice through various tasks and assignments. Mentoring from in-service teachers and other students where theoretical concepts are used to reflect on the students' own discretions, professional judgement, and choice of actions related to the staff and children's groups is equally important.

Below the aspects of profession-oriented, research-based, and practice-related education are discussed further as good conditions for the professional formation of (good) kindergarten teachers.

\section{Profession-oriented Education as a Condition for Kindergarten Teacher Professional Development}

Hennum \& Østrem [21] relate the exercise of the kindergarten teacher profession to the three following aspects: a) the social/political mandate; b) professional knowledge; and c) ethical and moral responsibilities, included in everyday work situations. This means that the kindergarten teacher's work is strongly related to certain norms. In other words, kindergarten teachers have a "corporate responsibility" [34] given to them by society. On the other hand, in the great majority of instances that require ethical and professional choices in the daily life of a kindergarten, the teacher is alone and "free" with no controlling or advisory presence.

Thus, it is professional knowledge that is used to justify ethical choices. The inseparable combination of professional knowledge and ethnical choice can be referred to as professional judgement $[21,35]$ that leads directly to certain actions taken when interacting with children/parents/personnel. This makes professional discretion and judgement the essence of the professional exercise, the essence that highlights the connection between knowledge, ethnics, and actions, and it is the 
essence that shows the inseparable character of professional ethnics and discretion in professional acts. Professional acts are an inseparable part of the exercise of the profession as work with children and people requires instant action. The meaning of the professional competences of kindergarten teachers can only be realized and seen through his/her actions and acts [35]; however, this also includes acts of speech since the professional kindergarten teacher is able to explain, justify, and reflect critically upon his/her own practice.

However, when it comes to acts of speech, which is the verbal use of professional knowledge in order to explain or justify certain actions, the use of professional language is reported infrequently, especially in interactions with non-qualified staff $[25,36,37,38]$. This might be seen as problematic for the profession. Eik, Steinnes, and Ødegård [37] state that professional language must be spoken to actualize various phenomena and professional understandings of situations during discussions among staff teams and their reflections on their practice. Thus, professional language is seen as a tool for understanding the complexity of kindergarten life and ongoing play, learning, care, and formation situations during the day. Professional work depends on professional language. Using professional language enables teachers to disseminate, decontextualize, and generalize situations and experiences in different kindergarten settings [36]. Nevertheless, this aspect of the exercise of the profession seems to be challenged. Johansson et al. [39] report that the values kindergartens stand for are often communicated by common language, ways of being, or rules. This means that the core values of the kindergarten often function as tacit knowledge, which regards skill-related knowledge of a "know-how" character [40, 41]. This limits significantly possibilities of reflecting on one's own practice since reflection requires professional categories. The lack of reflection leads to small changes and improvements in ongoing practice. This leads to the unconscious, unprofessional reproduction of certain practices that are neither in line with the national framework nor the concept of the kindergarten as a learning organization [25].

A professional kindergarten teacher in a learning organization of a kindergarten must, in contrast, be both able to establish patterns of acts and explain and justify them using professional categories. Articulation such as this is a condition for learning in a staff team and improving the quality of the units/kindergartens.

\section{How Can the Reformed Kindergarten Teacher Education Program Prepare Students to be Professionals?}

It seems that the practical training periods and role play activities during campus-based teaching are of great importance when thinking about developing professional competences to act [see also: 29], including verbal acts. Practical training periods provide the possibility to act in real kindergarten settings and to reflect on one's own acts during mentoring sessions provided by in-service teachers. Campus-based teaching and learning play crucial roles in equipping students with relevant theoretical concepts that are used as tools to reflect upon one's own actions. Nevertheless, there are certain challenges in making this happen. Since students start their practical training very early in their education, they do not have a chance to read all the required literature that would help them develop the conceptual framework for self-examination in relation to children and to reflect. This weakens the learning potential of the first practical training period. Another weak point is that in-service teachers are seldom up-to-date on current literature used in kindergarten teacher education, so they are not always able to support their students in their professional development with an up-to-date conceptual frame.

There is also a third weakness. In-service teachers seldom use professional language in their discourse with teams during daily work in the kindergarten $[25,36$, 37].The culture of toning down professional language socializes students into a nonprofessional practice since it is theoretical concepts meeting situated challenges that actualizes the professional exercise [42]. Moreover, students experience relative little dialogue and communication between the academic and in-service educators, which does not help them to build bridges between theory and practice in terms of actions, especially verbal actions [43]. Nevertheless, the students are generally satisfied with the study program and see it as the one that prepares them broadly for the profession and future work in kindergartens [46].

\section{Research-based Education as a Good Condition for the Professional Development of Kindergarten Teachers}

Since the daily ethical judgements of kindergarten teachers are based on professional knowledge, the quality of this knowledge and the abilities to (de)construct it are of great importance. The literature-based knowledge "served" to kindergarten teacher education students represents knowledge constructed using either deductive or inductive methodologies. This means that some of the "theories" (to use student language to describe literature-based knowledge that is primarily transmitted through campus-based teaching) are constructed on empirical or purely theoretical bases. Various methodologies are used in empirical studies (the validity of which is not always commonly recognized within the field). However, the status of "research" and "science" seems to prompt 
students to believe the texts whatever they say and however they relate to their own experiences.

To make students more analytical and critical as well as more literate in reading research, kindergarten teacher education is obliged to provide research-based learning processes so the students not only assimilate content, but also critically reflected on how it is generated and under which circumstances it is constructed [2]. Nevertheless, the National Guidelines for Kindergarten Teacher Education are rather general in describing research-based teaching and learning saying mainly only that the students will a) acquire knowledge about relevant research and developmental projects, and b) use research and developmental work methodologies to plan, lead, conduct, document, and reflect on their own professional work. Moreover, certain institutional practices are suggested as supportive of research-based teaching, namely: a) learning and work methods that support students' critical reflection; b) active institutional research in areas of knowledge relevant to kindergarten teacher education, and c) institutional research activities that involve students and that can support the research-based character of kindergarten teacher education [2].

The general formulations of the reform act mean that higher education institutions still discuss, develop, and implement various versions of it on their own campuses. They implement various ways of transmitting the newest research in the field by introducing the students into the theory of science and methodology up to student-initiated research projects to develop their own knowledge [44]. Working on their bachelor's theses, students aspire to acquire insight into different research perspectives and methodologies. A familiarity with research methods is supposed to support students in their search for scientific knowledge in the kindergarten field and help them to reflect on scientific truths in answering their own research questions, categorizing complexities, and analyzing data.

According to follow-up research on the implemented reforms [43, 45], the institutions running kindergarten teacher education programs have significantly developed and strengthened their research practices within the area of kindergarten teacher education. This is very positive, and this is also seen in interdisciplinary research projects inspired by new areas of knowledge in the field of kindergarten teacher education. Moreover, all institutions are working on developing research competences among academic teachers so that not only research results but also research methodologies are read critically. Nevertheless, those academics who are most involved in generating research-based knowledge and who are spending more and more time in their positions researching have less and less access to students. In other words, students usually do not meet famous researchers or knowledge constructors from their own institutions [43].

\section{Practice-related Education as a Good Condition for the Professional Development of Kindergarten Teachers}

Practical training in in-service kindergartens plays an important role of kindergarten teacher student development since it allows applying the knowledge that is "served" on campus in the safe frame of training with the supportive guidance of in-service teachers. Practical training is included in each the years of the course for a total of 100 days. There are certain learning outcomes for practical training in each year of the course, starting with leading groups of children and supporting their developmental activities (first year), applying professional tools and reflecting critically on one's own actions and leading staff and children groups (second year), and planning and conducting a developmental project, leading staff, and using documentation as a tool for reflection and improvement (third year).

To support the developmental potential of practical training, in-service teachers are obliged to take a 15 ECTS credit course in mentoring and supervising students. Practical training is meant to be an integral part of the education the purpose of which is to make the students aware of the importance of theory as the basis for professional practice.

Practical training can be understood (in the perspective of situated learning) as placing students in a community of practice [46] with a shared mission, and engagement and commitment embedded in activities performed. This allows students to experience living forms of professional knowledge. Even though students are "newcomers" in the field of practice, the situated learning theoretical framework does not view them as incompetent. The principles of the situated learning concept and the community of practice open up various ways of participating, diverse relationships, and all directions of knowledge flow [46]. Our experience shows that students are seen by in-service kindergartens as those who come with the newest theoretical concepts that inspire in-service teachers to examine their own practice through new lenses.

Although this does empower students as competent in in-service kindergartens, it is also a sign of the professional weakness of kindergartens. The lack of professional language or the use of current theoretical concepts in kindergarten practice as ways of socializing students into the profession are weaknesses of kindergarten teacher education. Kindergartens seem to deal with this weakness by "using" students who are up-to-date with current theory. This practice has grown across the field, and it is definitely not in line with the guidelines for kindergarten teacher education. 
In a way, this is mirrored in students' experiences of the educational program. They feel prepared for their future jobs [45], but they also report that the bridging between theory and practice is the weakest part of the educational program [45]. This indicates that students feel prepared for their future jobs in the knowledge that the field is theoretically weak, but not necessarily by being trained and prepared to act professionally in various settings in relation to children, parents, and fellow personnel. There is still room for improvement in achieving optimal coherence between theory and practice based on coherence between campus-based and in-service education. Høyhilder \& Lund Kristensen [47] suggest that educators and in-service teachers should leave their traditional roles for better coherence between campus-based and in-service education and for greater professional development in students. While partners may have different views on the need for scientific knowledge, they should aim to see each other as equal partners in educating students and facilitating the development in them of professional skills. They both have roles as teacher educators. Such thoughts can improve students' socialization into the professional life of kindergartens.

\section{Conclusions}

In conclusion, it is important to mention that any kind of improvements that strengthen kindergarten teacher education can be done at the level of society through new legislative apparatuses, new guidelines, or even new culture(s) for a "good childhood" and thereby "good teachers." Improvements done at this level could refer first of all to the proportions between qualified and unqualified staff in kindergartens. Currently, the proportion between teachers and assistants is 1:2. Non-professional staff constitutes approximately $66 \%$ of kindergarten personnel, which can challenge the professional socialization and development of kindergarten teacher education students (in addition to the effects of it experienced by children and parents). In our view, it may be disadvantageous that during their kindergarten teacher education students are exposed to unprofessional practices that contradict the knowledge they acquire on campus, which impedes them from becoming strong enough to articulate their professional standpoints [see also: 48]. This challenge could be mitigated by increasing teacher norms in kindergartens at the state level.

Making improvements in individual higher education institutions is equally important. Creating more and more possibilities for the exchange of knowledge and dialogue between both academic and in-service teacher educators is necessary if students are to be provided with the professional competences to act (including verbally) and to facilitate kindergartens functioning as learning organizations that continually improve their own quality in order to fulfil the needs of children for all-round development, care, play, learning, and formation on increasingly higher levels.

\section{REFERENCES}

[1] Norwegian Directorate of Education and Training. Framework Plan for Kindergartens: Contents and Tasks. Online available from: https://www.udir.no/globalassets/fil er/barnehage/rammeplan/framework-plan-for-kindergartens 2-2017.pdf

[2] Norwegian Ministry of Education and Research. Nasjonale retningslinjer for barnehagelærerutdanningen. Oslo, 2012. Online available from:https://www.uhr.no/_f/p1/i8dd41933 -bffl-433c-a82c-2110165de29d/blu-nasjonale-retningslinje r-ferdig-godkjent.pdf

[3] Norwegian Ministry of Education and Research. Stortingsmelding nr. 41. Kvalitet i barnehagen. 2008-2009. Online available from: https://www.regjeringen.no/no/doku menter/stmeld-nr-41-2008-2009-/id563868/

[4] B. Kristjánsson. The Making of the Nordic Childhood. In: J. Einarsdottir, J. T. Wagner (Eds.), Nordic Childhoods and Early Education: Philosophy, Research, Policy, and Practice in Denmark, Finland, Iceland, Norway, and Sweden. Information, Greenwich, 13-42. 2006.

[5] J. T. Wagner. An outsider's perspective: Childhoods and early education in the Nordic countries. In: J. Einersdottir, J.T. Wagner (Eds.), Nordic Childhoods and Early Education: Philosophy, Research, Policy, and Practice in Denmark, Finland, Iceland, Norway, and Sweden. Information, Greenwich, 289 - 306. 2006.

[6] A.R. Sadownik. Belonging and participation at stake. Polish migrant children about (mis)recognition of their needs in Norwegian ECECs. European Early Childhood Education Research Journal, Published on-line: 17 October 2018, p.1-16, 2018. DOI: DOI: 10.1080/1350293X.2018.1533711.

[7] Norwegian Ministry of Education and Research. Rammeplan for barnehagens innhold og oppgaver. Oslo. Kunnskapsdepartementet. 2011.

[8] Norwegian Ministry of Education and Research. Framework Plan for the Content and Tasks of Kindergartens.. Oslo. Kunnskapsdepartementet. 2006. Online available from: https://www.regjeringen.no/globalassets/upload/kd/vedlegg /barnehager/engelsk/frameworkplanforthecontentandtaskso fkindergartens.pdf

[9] Norwegian Ministry of Children and Family Affairs. Framework Plan for Day Care Institutions. Oslo. 1995. Online available from: http://www.ibe.unesco.org/fileadmi n/user_upload/Curriculum/SEEPDFs/daycare_norway.pdf.

[10] B. Bae. Realizing children's right to participation in early childhood settings: some critical issues in a Norwegian context. Early Years 30(3), 205-218. 2010.

[11] E.E. Ødegaard, I. Koreponova. Kindergarten as an arena for cultural formation. Cultural-Historical Psychology 2(2), 29-30. 2013. 
[12] S. Østrem. Barnet som subjekt. Etikk, demokrati og pedagogisk ansvar. Cappelen Damm Akademisk. Oslo. 2012.

[13] L.T. Grindheim. I'm not angry in the kindergarten! Interruptive anger as democratic participation in Norwegian kindergartens. Contemporary Issues in Early Childhood, Vol. 15. No. 4, 308-318. 2014.

[14] I. Pramling Samuelsson, M. Asplund Carlsson. The playing learning child: Towards a pedagogy of early childhood. Scandinavian Journal of Educational Research, Vol. 52, No. 6, 623- 641, 2008

[15] O.F. Lillemyr. Lek- opplevelse - læring i barnehage og skole. Universitetsforlaget. Oslo. 2004.

[16] L.T. Grindheim. Children as playing citizens. European Early Childhood Education Research Journal, Vol. 25(4), 624-636. 2017.

[17] J. Qvortrup. Chidlhood matters: an introduction. In: J. Qvortrup, M. Bardy, G. Sgritta, H. Wintersberger. Social Theory, Practice and Politcs, 1-24. Aveburty Press, Aldershot. 1994.

[18] M. Øsknes. Lekens flertydighet. Cappelen Akademisk Forlag. Oslo. 2010.

[19] J.H. Kallestad, E.E. Ødegaard. Children's activities in Norwegian kindergartens. Part 1: an overall picture. Cultural-Historical Psychology 9(4), 74-82. 2013

[20] Kindergarten Act No. 64 of June 2005 relating to kindergartens. Enacted 1. January 2006. Online available from:

https://www.regjeringen.no/globalassets/upload/kd/vedlegg /barnehager/engelsk/act_no_64_of_june_2005_web.pdf

[21] B.A. Hennum, S. Østrem. Barnehagelæreren som profesjonsutøver. Cappelen Damm Akademisk. Oslo. 2016.

[22] B. Bae, A. T. Fonnefoss. Barnes medivirkning i et relasjonelt perspektiv. Fagbokforlaget. Bergen. 2012.

[23] G- Løkken. Når små barn møtes. Cappelen Akademisk Forlag. Oslo. 1996.

[24] M. Sæther, T. L. Hagen (Eds.). Kreativ ute: Barnehagepedagogikk med uterommet som læringsarena. Fagbokforlaget. Bergen. 2014.

[25] W. Aasen. Teamledelse i barnehagen. Fagbokforlaget. Bergen. 2018.

[26] V. Glaser. Foreldresamarbeid. Barnehagen I et mangfoldig samfunn. Universitetsforlaget. Oslo. 2013

[27] A. Gunnestad. Didaktikk forførskolelærere. En innføring. Universitetsforlaget. Oslo 2007.

[28] A. Sadownik. W. Aasen, A. Visjnic-Jevtic. Norwegian and Croatian students of undergraduate kindergarten teacher education programs on their professional development and conditions for it. Universal Journal of Educational Research 7(3A): 8-21. 2019. DOI: 10.13189/ujer.2019.071302.

[29] K. Børhaug, I. Helgøy, A. Homme, D.Ø. Lotsberg, K. Ludvigsen. Styring, organisering og ledelse i barnehagen. Fagbokforlaget. Bergen. 2011.
[30] K. Kvistad, F. Søbstad. Kvalitetsarbeid i barnehagen. Cappelens Forlag A.S. Trondheim. 2005.

[31] Norwegian Ministry of Education and Research. White Paper no. 19. Tid for lek og læring - Bedre innhold $\mathrm{i}$ barnehagen. 2015-2016. Online available from: https://www.regjeringen.no/no/dokumenter/meld.-st.-19-20 152016/id2479078/

[32] Norwegian Ministry of Education and Research. White Paper no. 19. Kvalitet i barnehagen. 2008-2009. Online available from: https://www.regjeringen.no/no/dokumenter/ stmeld-nr-41-2008-2009-/id563868/

[33] L.T. Grindheim. Kva skal den profesjonelle barnehagelæreren bruke tid til? In: L.T. Grindheim, T. Kruger, P.E. Leirhaug, D. Wilson (Eds.). Lærerprofesjonalitet i utdanningspraksiser. Fagbokforlaget. Bergen. 2016.

[34] M. van Manen. Pedagogisk takt. Betydningen av pedagogigsk omtenksomhet. Caspar Forlag. Oslo. 1993.

[35] L.T. Eik. Førskolelærerens profesjonsspråk. FOU i praksis. Akademisk Forlag, Trondheim. 2013.

[36] L.T. Eik, G.S. Steinnes, E. Ødegård. Barnehagelærerens profesjonslæring. Fagbokforlaget. Bergen. 2016.

[37] T.T. Jansen. En lærer underviser, hva gjør en førskolelærer. In: T. T. Jansen et al. (Eds.). Førskolelæreren. Pedagogisk Forum, Oslo. 2006.

[38] E. Johansson, K. Fugelsnes, E.L. Møreseth, M. Røthle, B. Tøfteland, B. Zachrisen. Verdipedagogikk i barnehagen. Universitetsforlaget. Oslo. 2015.

[39] M. Polyani. The tacit dimension. Doubleday, New York. 1966.

[40] G. Ryle. The Concept of Mind. Penguin, Harmodsworth. 1963.

[41] J.C. Smeby, Profesjon og utdanning. In: A. Molander, L. I. Terum (Eds.) Profesjonsstudier. Universitetsforlaget. Oslo. 2008.

[42] Følgegruppe for barnehagelærerutdanning. Barnehageyrket og barnehagelærerutdanningen. Delrapport 1. 2016. Online available from: https://blu.hib.no/wp-content/uploads/2016/ 02/RAPPORT-Delrapport1-2016.pdf

[43] H. I. Strømsø. Forskningsbasert undervisning. In: P. Lauvås, K. H. Lycke, H. I. Strømsø (Eds.). Når læring er det viktigste: undervisning i høyere utdanning, 40- 53, Cappelen Damm AS. Oslo. 2016.

[44] Følgegruppe for barnehagelærerutdanning. Barnehagelærerutdanninga i reform. Studenterfaringar 2014-2016. Samlerapport. 2017. Online available from: https://blu.hib.no/wp-content/uploads/2017/02/BLU-14021 7.pdf

[45] J. Lave, E. Wenger. Situated Learning - Legitimate Peripheral Participation. Cambridge University Press. Cambridge. 1991.

[46] E. K. Høihilder, H. Lund-Kristensen (Eds.). Praksisbarnehagen. En arena for læring. Gylendal akademisk. Oslo. 2017. 